\title{
Gender, family and career in the era of boundarylessness: determinants and effects of intra- and inter-organizational mobility
}

\section{P. Monique Valcour and Pamela S. Tolbert.}

Changes in patterns of long-term employment make understanding the determinants of different career forms increasingly important to careers research. At the same time, the rise of dual-earner families demands greater attention to the ways in which gender and family characteristics shape careers than has been paid by traditional research. This paper addresses these issues, examining the determinants and consequences of intra-organizational and inter-organizational mobility, using a sample of employees from dual-earner couples. We find significant gender differences in these different types of career mobility, and in the effect of family relations on different forms of mobility. Women experience more inter-organizational mobility, while men experience more intra-organizational mobility. Having more children positively influences men's intra-organizational mobility, but increases interorganizational mobility for women. Marital instability increases intra-organizational mobility among women, but has no effect among men. Each form of mobility has distinctive effects on objective and subjective indicators of career success for both men and women. Moving between organizations tends to depress earnings, but has no effect on how successful people feel in their careers. Job changes within an organization increase earnings, but have a negative effect on perceived success.

Keywords Career mobility; success; boundaryless careers; gender differences; family.

Much of the research published on careers up through the 1980 s was based on the assumption that 'normal' careers (versus 'disorderly' careers) involved continuous, fulltime employment with a single employer, and a sequence of jobs characterized by increasing levels of prestige, authority and pay (e.g. Rosenbaum, 1979; Spilerman, 1977; Wilensky, 1961). The prototypical career holder was also implicitly male; little attention was paid to the potential differences in gender or the impact of family structure on careers.

Work on careers within the last decade, however, suggests that this model of employment describes a declining proportion of the workforce in many industrialized countries, including the US (Arthur et al., 1999; Cappelli, 1999; Osterman, 1996), Britain, (Arnold, 1997), France (Cadin et al., 2000), New Zealand (Arthur et al., 1999), Canada (Gunz et al., 2000) and even Japan (Zaun and Landers, 2001). Even for managerial employees, who typically enjoy the greatest level of employment security and the most extensive employer support of and investment in their career development, average job and organizational tenure have declined, and organizational career development ladders have become much less common (Heckscher, 1995). Both employer commitment to employees and employee loyalty to employers have waned considerably (Tsui et al., 1997). Inter-organizational mobility should therefore figure as prominently in contemporary studies of careers as intra-organizational mobility has in past research.

Widespread changes in women's rates of labour-force participation over the last twenty years have also raised new issues for research on careers. In tandem with an overall shift in the gender composition of the workforce, women have increasingly gained entry to what were once exclusively male career paths (Blau et al., 2002). Thus, how career paths may differ by gender is a question that merits careful exploration. Also, as a result of women's increased labour-force participation, the dual-earner family is now the modal family type within the most industrialized societies (Stier et al., 2001). In couples where both the husband and wife are members of the 
paid workforce, problems of balancing work and family demands are apt to become important influences on men's as well as women's careers (Moen, 2001).

These changes in the contemporary workplace point to the need for a better understanding of the determinants of inter- as well as intra-organizational mobility, and for more attention to the impact of gender and family variables on both forms of mobility. We address these issues in a comparison of job transitions within and across employers. The study of job transitions within organizations has traditionally been one of the key focuses of careers research. More recently, the notion of boundaryless careers - with its inherent emphasis on crossemployer movement - has been suggested as a theoretical alternative to traditional conceptualizations of careers and career mobility (Arthur and Rousseau, 1996; Baker and Aldrich, 1996). We investigate the relative impact of individual, occupational and family characteristics on these two forms of mobility, paying particular attention to gender differences in our analysis. In addition, we examine how these two career mobility patterns are related to individuals' objective and subjective career success.

\section{Forms and sources of mobility}

\section{Intra-organizational mobility}

In its broadest sense, the concept of career refers to a patterning of individuals' work histories and experiences (Arthur et al., 1989; Blair-Loy, 1999). One of the key dimensions of such patterning is the degree of movement by individuals among jobs over time, both within organizations (as conventional views of careers have emphasized) and across organizations (as the notion of boundaryless careers emphasizes). Following more conventional approaches to careers, research to date has tended to focus on intraorganizational movement. Much of the work on this problem has concentrated on organizational characteristics and job-related individual characteristics as determinants of mobility (e.g. Barnett and Miner, 1992; Cohen et al., 1998; Hurley and Sonnenfeld, 1998; Rosenbaum, 1984; Stewman and Konda, 1983).

More recent studies of intra-organizational mobility have begun to pay attention to the role of gender and family characteristics in shaping career patterns. Several studies have shown that, all else being equal, women are less likely to be promoted than men (DiPrete and Soule, 1986; Schneer and Reitman, 1995; Stroh et al., 1992). Less direct attention has been paid to the role of family characteristics in determining promotion chances, but some inferences can be drawn from studies that have examined earnings attainment, since earnings and promotions are closely related (Cox and Harquail, 1991; Lyness and Thompson, 2000). Marriage has been shown to have a positive effect on men's earnings, but not women's (Hill, 1979; Korenman and Neumark, 1991; Pfeffer and Ross, 1982). This probably reflects the fact that the traditional, gendered division of labour in the family relieves men from most domestic responsibilities; women, on the other hand, usually take on a heavier load of domestic chores with marriage (Hochschild, 1989; Pleck, 1985). In line with this, Han and Moen (1998), in one of the few studies focusing directly on the impact of marriage on career paths, found a negative relationship between marital stability and the successful pursuit of traditional, upwardly mobile careers by women. Tichenor (1999) found that, even when women are the main earners in families and their careers are given priority, the traditional, gendered division of labour at home still largely persists.

In addition, having children has been shown to affect internal mobility for both men and women. Gattiker and Larwood (1988) found that number of children was positively related to the amount of time spent in the current position (time since promotion, which implies low intra-organizational mobility). These correlations were not computed separately by gender, so there is no indication whether having children affected men's and 
women's career paths differently. However, research has shown that having children depresses women's earnings, but not men's (Hill, 1979; Korenman and Neumark, 1992). This is consistent with the existence of social norms that assign women primary responsibility for child care. The additional financial responsibilities of having children tend to increase men's attachment to their employer (and, thus, their intra-organizational mobility) and to decrease their propensity to change employers (Blau et al., 2002). It is also possible that such findings may reflect employers' behaviour to some degree as well. amount of work experience which, in turn, reduced the amount of training women received from employers; training was shown to be an important determinant of managerial advancement. Thus, focusing on the impact of gender and family on intra-organizational mobility, we propose:

Hypothesis 1: Women will have less intra-organizational mobility than men.

Hypothesis 2: Marital stability will have a positive effect on intra-organizational mobility for men, but not for women.

Hypothesis 3: Having children will have a positive effect on intra-organizational mobility for men but not women.

Inter-organizational mobility

The concept of the boundaryless career has been proposed to emphasize an increasingly common pattern of employment relations (Arthur and Rousseau, 1996), one that is independent of, rather than dependent on, traditional organizational career systems (Arthur and Rousseau, 1996: 6). Changes in career patterns reflect changes in employment practices that occurred in many companies world-wide in the late 1980s, resulting in increased lay-offs and declining job security. These workplace changes were accompanied by shifts in the demographic composition of the workforce, and in individuals' work values, as well. In combination, these shifts have led many employees to de-emphasize attachment to a single employer as a career strategy (Arnold, 1997; Cappelli, 1999; Tolbert, 1996). In this context, understanding the factors that influence rates of inter-organizational mobility is clearly important to the study of contemporary careers. However, though the concept of boundaryless careers has generated much theoretical work, relatively little empirical work has examined determinants of this career pattern.

Extant work on the determinants of inter-organizational mobility has tended to focus on characteristics that are related to the risks and potential benefits to the individual of making an employment switch, such as age and education. For example, older workers, who are more likely to have developed firm-specific knowledge and skills with a given employer, are apt to have more to lose from changing employers (Hirsch and Shanley, 1996). Similarly, education can be used to index potential costs and benefits of changing employers, although competing arguments have been made about its effects. For example, it has been argued that more educated employees have more opportunities for inter-organizational mobility because they have skills and knowledge that are attractive to many employers (Blau et al., 2002; Brett and Stroh, 1997). Alternatively, it could be argued that employers are likely to offer greater inducements to more educated workers to remain with the firm, thus depressing their propensity to change employers (see Nardone et al. (1997) for evidence consistent with this argument).

More recently, findings from several studies, indicating that women are more likely to change employers than men, have led to some recognition of the role of family factors in influencing inter-organizational mobility. A recent study (Lyness and Thompson, 2000) examining the movement of sixty-nine male and female executives found no gender difference in rates of inter-organizational mobility, but this study did not include measures of 
marital or parental status. In contrast, Felmlee (1982) found that the women in her study had four times as many inter- as intra-organizational job shifts, and that such mobility was positively related to marriage. Several other studies (Brett and Stroh, 1997; Schneer and Reitman, 1995; Stroh et al., 1996) indicate that women leave their employing organizations more frequently than men. This may reflect the propensity of women to make sacrifices in their own careers for the sake of their husbands'. Han and Moen $(1998,1999)$ surveying married couples nearing or at retirement age, found that wives' career experiences tended to be contingent on their husbands' career trajectories. Most of the men in their study had careers marked by continuous full-time employment and upward mobility, while women more frequently delayed the start of their careers, worked intermittently or worked on a part-time basis. Similarly, using data from the 1977 Quality of Employment Survey, Bielby and Bielby (1992) found that couples' gender role beliefs, specifically their orientation to the stereotypically male 'provider' role, influenced their responses to job opportunities requiring relocation. Men with traditional gender-role beliefs were unwilling to allow their wives' jobs to interfere with their own advancement, while traditional women reported being willing to sacrifice their own job advancement opportunities in order to avoid jeopardizing their husbands' well-paying jobs (see also Mincer, 1978).

All in all, these findings suggest that, for dual-earner couples, men's careers are more frequently given priority when decisions are made that may affect both spouses' careers (Pixley, 2000). It follows logically that, in the frequent case that a husband is offered a job opportunity that may impact on his wife's career (such as a job transfer to another geographical location), the decision will be made in favour of the husband's career, resulting in potential disruption to the wife's continuous employment with her employing organization. Women whose job histories are intermittent have higher inter-organizational mobility than do women with orderly careers or men (Han and Moen, 1998).

Although Felmlee (1982) found no direct evidence of the impact of having children on women's interorganizational mobility, other work suggests strong effects, and indicates that women are more likely than men to restructure their work lives in order to accommodate family responsibilities (Brett and Yogev, 1988; Karambayya and Reilly, 1992). Having children is likely to result in the disruption of women's employment continuity, because women often take time out of the workforce for childcare (Schneer and Reitman, 1990, 1997).

Thus, we hypothesize that gender will affect rates of inter-organizational mobility, and that there will be gender differences in the effects of family on this outcome.

Hypothesis 4: Women will have higher rates of inter-organizational mobility than men.

Hypothesis 5: Marital stability will have a positive effect on inter-organizational mobility for women but not for men.

Hypothesis 6: Having children will increase inter-organizational mobility for women but not for men.

Hypothesis 7: Having one's career assigned priority in a couple will reduce men's interorganizational mobility, but not women's.

\section{Effects of intra- and inter-organizational mobility on career success}

Objective indicators of success 
Several studies have established the career benefits of moving up with a single employer. Number of promotions is a strong predictor of both earnings and managerial attainment (Hurley and Sonnenfeld, 1998; Rosenbaum, 1984). Researchers have found positive relationships between earnings and organizational tenure (Brett and Stroh, 1997; Marcotte, 1998; Scandura, 1992). There is evidence, however, that intra-organizational mobility has a greater impact on men's earnings than on women's (Kirchmeyer, 1998; Lyness and Thompson, 2000; Stroh et al., 1996). Even when women do 'all the right stuff' (e.g. getting a similar education as the men, maintaining similar levels of family power, working in similar industries, not moving in and out of the workforce, not removing their names from consideration for a transfer more often), they still lag behind men in salary progression (Stroh et al., 1992).

On the other hand, some evidence suggests that managerial employees can achieve greater earnings by moving from one employer to another (Brett and Stroh, 1997). One explanation for this phenomenon is that companies that hire managers from outside the organization do not emphasize career development and security. Rather, they offer higher levels of compensation in exchange for the lack of employment security (Pfeffer and Baron, 1988; Sonnenfeld and Peiperl, 1988). The strategic emphasis in such firms is on purchasing skills valuable to the firm when such skills are needed, requiring the provision of extra inducements to employees to enter into this sort of transactional employment relationship. Also, since employees who already have a job have a fair amount of bargaining power when considering a switch to another employer, an argument can be made that interorganizational job changes will result in higher earnings. A study which found that longer organizational tenure predicted lower rates of salary progression between two time periods provides support for this argument (Wayne et al., 1999).

Still, evidence of the effect of inter-organizational mobility on earnings is not conclusive. Peiperl and Van Der Sluis (1999) found no differences in income between MBA graduates who changed employers and those who did not, while Lyness and Thompson (2000) found that a history of inter-organizational mobility was negatively related to income. An examination of gender effects may help to explain these discrepancies. Both Dreher and Cox (2000) and Brett and Stroh (1997) found that interorganizational movement was associated with higher earnings among male managers only, not female managers. This relationship may be due to the fact that men have better access to social networks that supply information instrumental to career development and job opportunities in other organizations (Ibarra, 1992, 1993).

Thus, using earnings as an objective indicator of career success, we hypothesize the following:

\section{Hypothesis 8: Intra-organizational mobility will positively influence men's earnings, but not} women's.

Hypothesis 9: Inter-organizational mobility will positively influence men's earnings, but not women's.

\section{Subjective indicators of success}

From a psychological perspective, a career is defined as 'the individually perceived sequence of attitudes and behaviors associated with work-related experiences and activities over the span of a person's life' (Hall, 1976: 4). Thus, subjective career success refers to people's perceptions of how successful their careers are, independent of observable indicators such as salary or hierarchical attainment. This aspect of career success is typically assessed with measures of satisfaction with global career success or facets of career achievement including satisfaction with pay, promotions and the development of skills (Greenhaus et al., 1990; Turban and Dougherty, 1994). While it 
might be expected that people who are outwardly successful in their careers will also feel successful, evidence indicates that objective and subjective career success do not necessarily co-vary (Evans and Bartolomé, 1980; Korman et al., 1981). Past research has found that different variables predict objective and subjective career success (Judge et al., 1995; Parasuraman et al., 1996; Wayne et al., 1999).

Consideration of subjective success is particularly important in the boundaryless career because boundaryless careers do not follow a normative template in the same way traditional careers do, and they lack agreed-upon indicators with which to index success. Mirvis and Hall (1996: 238) note that many of the factors that support and reinforce psychological success in a traditional career - such as job security, ever-increasing levels of income and the status that derives from one's position and employer - are much less likely to be present in a boundaryless career.

It is unclear how high rates of inter-organizational mobility will affect individuals' perceptions of career success, and arguments can be made for both positive and negative effects of this form of mobility on perceived success. On the one hand, Baker and Aldrich (1996) argue that the boundaryless organization is more institutionalized than the boundaryless career. That is, "norms have emerged more quickly for employer, than for employee, behavior, in the sense that employers accept the termination of unwanted employees as a routine management practice, but are still uncertain about how to interpret multiple job changes by employees' (Baker and Aldrich, 1996: 140). Insofar as employees' self-perceptions reflect employers' evaluations, high rates of interorganizational mobility may negatively influence subjective career success. On the other hand, Sekaran and Hall (1989: 176) argue that the work force at large (and not just two-career couples) has already adopted a more individualized, protean definition of success, which stresses autonomy, flexibility, and balance between work and home'. They argue that individualized definitions of success that do not involve hierarchical advancement are already pervasive in the workforce, but have not yet become institutionalized among employers. Greater interorganizational mobility may provide more opportunities for developing new skills, finding challenging work, and aligning careers with individual values, thus potentially increasing subjective success (Ellig and Thatchenkery, 1996). Thus, we hypothesize:

\section{Hypothesis 10: Individuals who have higher levels of inter-organizational mobility will perceive themselves as more successful in their careers. \\ Hypothesis 11: Individuals who have greater levels of intra-organizational mobility will perceive themselves as less successful in their careers.}

We further expect that gender will affect the relationship between mobility and subjective success. The boundaryless or protean career model comes closer to describing women's typical pattern of work history accurately than does the traditional career model. Consequently, women may be more comfortable with the job sequences of the boundaryless career and more apt to feel successful as they negotiate the construction of their own careers (Bailyn, 1989; Fondas, 1996; Gallos, 1989). While many men, particularly those in later career stages, may struggle with the shift toward a career model in which hierarchical advancement receives less emphasis, women will have less distance to cover in making this adjustment. Thus:

Hypothesis 12: Higher levels of inter-organizational mobility will increase women's perceived career success more than men's.

\section{Method}


The research reported here is part of the larger 1998 Cornell Couples and Careers Study of dual-earner couples (Moen, 2003). This study focuses on the career and family experiences of primarily professional and managerial dual-earner couples, a population likely both to identify themselves as having careers (in the common use of the term) and to face pressures - particularly stemming from the challenge of balancing dual careers -that lead to the pursuit of a boundaryless career (Arthur and Rousseau, 1996). Potential study participants were identified through seven large US employers in upstate New York. In order to be eligible for participation in the study, respondents had to be members of dual-earner couples (married or cohabiting) and currently employed if over age 30 . The only inclusion requirement for workers under the age of 30 was that they be employed.

The seven participating organizations exemplify a variety of workplace cultures and practices and were chosen to represent four key regional economic sectors: manufacturing (two organizations), healthcare (two organizations), higher education (two universities) and utilities (one company). These employers sent their exempt (salaried) employees a letter inviting them to participate in the Cornell study. Due to employer concerns about confidentiality, the participating organizations did not provide access to information about those respondents who did not return response cards. Therefore, we are unable to estimate accurately our response rate to the initial mailing. However, of employees who did return the postcard expressing initial interest, 75 per cent completed the one-hour telephone survey. Fifteen per cent of those returning cards were not eligible to participate because they did not meet our criteria due to circumstances such as divorce or lay-off. The spouses of participating employees were contacted on a separate occasion to answer the survey.

\section{Sample}

The sample for this study consists of 1,890 individuals. Nine hundred and sixty-seven respondents are male and 923 are female, and the average age is 44 . Eighty-seven per cent have at least one child. Seventy per cent of respondents are managerial or professional employees, 15 per cent are technical employees, and the remaining 15 per cent are sales, service, production or administrative support workers. Equal proportions of men and women are employed in managerial and professional jobs. Men are somewhat more likely to work in technical positions, while women are more likely to be employed as administrative support staff.

Measures

Our key variables, measuring job mobility within and across employers, were based on a series of questions each respondent was asked about the jobs they had held from age 30 to the time of the interview. For each job, respondents indicated whether it was with the same employer as the previous job, and the length of time they had held it. Using this information, we counted the total number of job changes with the same employer (intraorganizational mobility) and the total number of job changes that involved moving from one employer to another (inter-organizational mobility).

The mobility variables were regressed on a set of variables measuring individual, family and occupational characteristics. A central control variable, labour force experience, measured the total number of years that respondents had been in the labour force. Although the rate of voluntary job shifts generally declines with time spent in the labour force (Rosenfeld, 1992), individuals with longer labour-force experience are, ceteris paribus, likely to have had more opportunities for both intra- and interorganizational mobility. Education, also included as a control variable, was measured as the total number of years of formal education beyond high school. A third control variable, occupational prestige, is based upon the Standard Occupational Classification (SOC) code; prestige scores for current job were assigned following the methodology of Nakao et al. (1990). Because variations in 
perceptions of success may be partly a function of individual dispositional differences (Boudreau et al., 2001), we included a measure of negative affect in the regressions of subjective career success. The negative affect measure, adapted from Mroczek and Kolarz (1998), asked employees to rate on a 5-point scale how frequently in the past month they have felt: in good spirits, so sad that nothing could cheer them up, restless or fidgety, nervous or that everything was an effort (alpha $=.61$ ).

Gender is a dummy variable coded ' 1 ' for women. To measure marital stability, we used a self-reported measure of the number of times a respondent has been married or living in a committed relationship. To measure the effects of having children on careers, we included a count variable of how many children each respondent has. Both of these latter measures were constructed from life history variables. Respondents were asked, 'Think about all of the major decisions that you and your spouse/partner have made since you have been together, such as changing jobs, having children, going back to school or moving. Overall, whose career was given more priority in these decisions, yours or your spouse/partner's?' Based on responses to this question, we constructed a measure of career priority, a dichotomous measure where ' 1 ' signified that the respondent's career was given priority and ' 0 ' indicated that the respondent's career was not consistently given priority.

We were interested in objective and subjective success as outcomes of the two types of mobility. Objective career success was operationalized as earnings, the respondents' self-reports of their current annual salary from paid employment, including any bonuses, overtime and/or commissions, before taxes and other deductions. Subjective, or perceived career success, was measured with a single item that asked respondents to assess how successful they feel in their work lives, measured on a scale of 0 to 100 .

\section{Results}

Table 1 includes descriptive statistics for the variables used in the regression analysis, including differences in means between men and women. Men have four years' more labour-market experience, on average, 19.76 years versus $\mathbf{1 5 . 6 9}$ years for women. They are also slightly more educated, and the occupational prestige scores for their jobs are somewhat higher. Men are significantly more likely to report that their career has consistently been given priority over their spouses'. Interestingly, men also report having more children than women. This is probably due to the high representation of women in this sample with a strong career orientation: a relatively large proportion of women are in professional and managerial occupations, compared to the population as a whole. Such women often have smaller families than less career-oriented women. In contrast, career orientation is much less likely to affect the number of children that men have (Gattiker and Larwood, 1988). Average annual earnings for the overall sample are $\$ 54,062$, but men earn significantly more than women: $\$ 66,412$ versus $\$ 41,130$. Nevertheless, women rate their level of career success slightly higher than do men.

Table 2 reports the correlations between variables in the study. Worth noting here is the relatively strong negative relation between intra-organizational and interorganizational mobility $(-.28)$. Thus, the more frequently people move within an organization, the less likely they are to change employers, and vice versa. (Separate analyses, not reported here, showed that the magnitude of the correlation between these two variables is similar for men and women.) Hypothesis 1 predicted than men would have more intra-organizational mobility than women, while hypothesis 4 predicted that women would have more inter-organizational mobility than men. Consistent with these hypotheses, Table 1 indicates that men have a significantly higher number of intraorganizational job changes, on average, while women have a higher number of inter-organizational job shifts. Likewise, in the first model of Table 3 (which presents the results of the regression of intra-organizational mobility on the independent predictors), using the combined sample of men and women, the significant, negative 


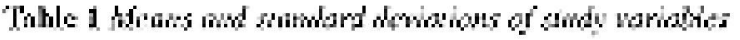

\begin{tabular}{|c|c|c|c|c|c|c|}
\hline & \multicolumn{2}{|c|}{$N^{A}$} & \multicolumn{2}{|c|}{ Wo } & \multicolumn{2}{|c|}{ Wowa } \\
\hline & Haw & $5 D$ & Whan & $S D$ & Hem & $3 . D$ \\
\hline [Abor bos sprincs & 17.77 & 906 & 19.76 & 9.56 & 1569 & 7.960 \\
\hline cirong & $0+9$ & 050 & $0 t$ & 000 & 10 & not \\
\hline Buantion & 4.43 & 2.76 & 468 & $2.8:$ & 3.95 & 26000 \\
\hline Olesilpilstal pesigs & 54.02 & 1087 & 55.4 & 1079 & 517 & $1051^{\mathrm{m}}$ \\
\hline homber of matringes & $12+$ & 054 & 124 & 0.54 & 12 & 15 \\
\hline Aumber ol childret & 205 & 1.26 & 2.15 & 1.91 & 1.95 & 1.21000 \\
\hline Somat penty & 139 & 040 & 0.50 & 0.49 & 018 & $030 \%$ \\
\hline $\begin{array}{l}\text { tho tinm-agnizational } \\
\text { mons }\end{array}$ & 1.45 & 18 & 168 & 2.93 & 1.21 & 1.57006 \\
\hline 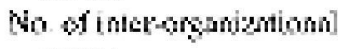 & & & & & & \\
\hline $\operatorname{mons}$ & $2+10$ & $1 \%$ & 25 & 1.56 & 24 & $161^{6}$ \\
\hline Annmil samings & 34,4 & 54,43 & 54,412 & $\$ 8,618$ & $y=1,131$ & 916,71040 \\
\hline Sinbj cante siloss & 795 & 1358 & 78.59 & 13.40 & 8052 & 137100 \\
\hline
\end{tabular}

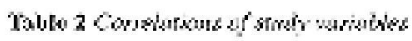

\begin{tabular}{|c|c|c|c|c|c|c|c|c|c|c|c|c|c|}
\hline & & 1 & 2 & 5 & $F$ & 5 & 6 & 7 & 8 & $y$ & 10 & $i$ & 12 \\
\hline $\mathbf{1}$ & 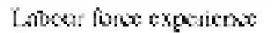 & 1 & & & & & & & & & & & \\
\hline 2 & Gender & $-0,20$ & ] & & & & & & & & & & \\
\hline 3 & Eulusiltall & 0.14 & $-1,1] \mathrm{j}$ & L & & & & & & & & & \\
\hline+ & Mnpaimal prostig: & aner & $-\left[11^{x=x}\right.$ & $0+4^{2=2}$ & ] & & & & & & & & \\
\hline 5 & Nuniler $\alpha$ minnget & $0.10+\%$ & -101 & 002 & -101 & 1 & & & & & & & \\
\hline 6 & Number $\alpha$ etslown & $0,12+6$ & $-1108 \mathrm{mox}$ & Dogare & 1002 & $00 \%$ & 1 & & & & & & \\
\hline 7 & Guen puony & $0.1+\operatorname{tat}$ & $-[-1+1+x$ & $0.12^{5 x+2}$ & {$[1] A^{*-5}$} & -opts & $0+6=$ & ] & & & & & \\
\hline 8 & 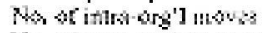 & cinets & $-12=\infty$ & D] $13 \times$ & nos: & op & 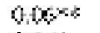 & 1500 & 1 & & & & \\
\hline 9 & No ar inter-og'L Inons & $0.18^{+\infty}$ & $110 \%$ & -001 & $-1107 \%$ & oluter & $\theta \mathrm{n}^{2}$ & $+12+12 x$ & $-0.26=$ & 1 & & & \\
\hline 10 & 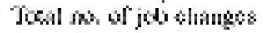 & $021 \mathrm{crs}$ & $-\pi, y^{*=}$ & p.19:e & $\pi 00$ & oper & $0,100 e t$ & $\operatorname{mos}$ & t.7nget & $0-90<$ & ] & & \\
\hline 11 & Anwh carnings & $0,20+4$ & $-[\mathrm{L}+2=\infty$ & $000 \times 6$ & 43350 & 00 & $0 \%$ & $1037 \% \times$ & $0,1]<k$ & $-0.19 \infty$ & D. $14: x$ & & 1 \\
\hline 12 & Stbl surer ances & $0.16 \times x$ & $1107 \%$ & 001 & $110,8 \%$ & aps & $0,4=$ & 001 & $-0,147$ & 00 & -102 & pogers & \\
\hline
\end{tabular}

coefficient for gender indicates that, net of other factors, women experience fewer job changes within an employing organization than men do.

To explore gender differences in the effects of family factors, we ran separate analyses for men and women; the results are shown in the second and third panels of Table 3. The measure of marital instability is negative but non-significant for men. However, this measure is positive and significant for women, suggesting that the pursuit of mobility within an organization may impose constraints on women that are not compatible with traditional gendered marital roles. Thus, these results provide some support for hypothesis 2 . As posited in hypothesis 3 , having more children is positively related to internal mobility for men, but negatively for women.

Table 4 presents results of analyses of the determinants of inter-organizational, or between-employer, mobility. In the first panel, showing results from analyses with both men and women combined, the coefficient for gender is again significant; the positive sign indicates that women are likely to have more employer changes than men, even after controlling for other variables that might affect mobility. This provides support for hypothesis 4.

In the second panel of the table, showing the models for men only, the significant, positive coefficient for number of marriages indicates that marital instability is associated with more frequent change of employers. 
Interestingly, the third panel, presenting analogous results for women, shows that this variable has no significant effect for women. These results are somewhat different from those postulated in hypothesis 5 , which is based on the premise that women who stay married are more likely to make job switches to accommodate their husbands' careers. Marriage, per se, does not have a direct relationship with women's inter-organizational mobility. Increases in the number of children, on the other hand, are associated with increases in women's propensity to change employers, though not men's, as posited in hypothesis 6 . The negative, significant coefficient for the measure of career priority in the model for men and the lack of impact of this variable in the counterpart model for women provides support for hypothesis 7.

Table 5 shows the coefficients from the regression of earnings, as an objective measure of success, on predictor variables. Contrary to hypotheses 8 and 9 , there are no gender differences in the effects of intra- and inter-organizational mobility on this aspect of career success. The significant, negative coefficient for gender in the first panel of the table indicates that women earn significantly less than men, even after controlling for length of labour force experience and education. But for both men and women, greater intra-organizational mobility is associated with higher earnings. If anything, women actually receive a greater return for such mobility. In contrast, the coefficients for interorganizational mobility are significantly negative, in the analyses for men and women combined, as well as in the separate analyses, suggesting that boundaryless career patterns are apt to come with financial penalties.

Hypothesis 10 predicted that people with higher rates of inter-organizational mobility would be more likely to perceive themselves as successful, independent of objective indicators of career success, while hypothesis 11 predicted that people with higher levels of intra-organizational mobility would feel less successful. Results shown in Table 6 support the latter hypothesis, but not the former. Net of other factors (including earnings), individuals who experience more frequent movement within an employer tend to perceive themselves as less successful than others with less movement. It may be that such mobility increases aspirations and results in a

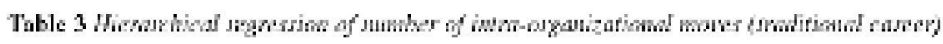

\begin{tabular}{|c|c|c|c|c|c|c|c|c|c|c|c|c|}
\hline \multirow[b]{2}{*}{ Prothor } & \multicolumn{4}{|c|}{$A l i$} & \multicolumn{4}{|c|}{ Man } & \multicolumn{4}{|c|}{ Mann: } \\
\hline & Cor & SEt & Bingr & 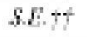 & Cop. & SEt & $\cos$ & $S E+t^{2}$ & $\cos$ & SEP & Cot & $B E+$ \\
\hline Tabour foras experienes & $0.012^{\circ}$ & whos & $0.024^{\circ} \%$ & 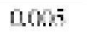 & nok & 1007 & Du19*\% & 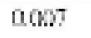 & 0.1515 & now & $0.927=6 \%$ & ang \\
\hline Edwatmal & Donzoce & apts & Dongtoct & 0017 & 0056 & 008 & Duspor & 0027 & abges & 002 & nothes & and \\
\hline focuptional prestige & -1.0.14 & ans & -ดติรt & nond & mons & 1.607 & -nดl & nowt & $-4 \operatorname{los}$ & uns & tunt & 6.105 \\
\hline Wh of manises & $-\log 3$ & 6185 & คดติส & nots & $-1,12$ & 0135 & Dô1 & 0130 & 0.157 & $100 y$ & $1 \mathrm{t}+3=$ & $a m$ \\
\hline No of chiblen & Dnstye & ans, & 1). $1 \mathrm{H}^{5}$ & 11064 & $\mathrm{D}_{2} \mathrm{sen}$ & 1065 & 0217 the & 005 & Aluentes & nots & -1105 & 0112 \\
\hline $\mathrm{No}$ inter-my i mons & & & $-10360^{\text {ort }}$ & 00027 & & & $-0.73^{4+4}$ & 2045 & & & $-1,282^{-4}$ & and \\
\hline Intersept & D.78\% & 627 & 1.95 oret & 12200 & $6887^{\circ}$ & 043 & 1.955 oret & $10+28$ & andst & $11 \mathrm{~m}$ & $13110+8$ & 0.24 \\
\hline $\mathrm{N}$ & Inst & & 189 & & $\sin$ & & 467 & & 525 & & 923 & \\
\hline $\mathrm{P}$ & $11.60^{60}$ & & 3,57004 & & 851 th & & $21.2704 \mathrm{~m}$ & & 5,51400 & & $169^{\circ}=$ & \\
\hline alj k-syimed & 0.14 & & 1213 & & 014 & & 0.7 & & $a .0$ & & 0.11 & \\
\hline thg. in adj k-squand & & & מ.ด & & & & מิต & & & & ons & \\
\hline
\end{tabular}

Notes

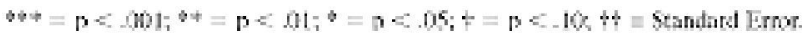




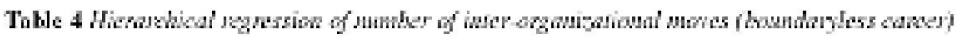

\begin{tabular}{|c|c|c|c|c|c|c|c|c|c|c|c|c|}
\hline \multirow[b]{2}{*}{ Frolicur } & \multicolumn{4}{|c|}{$A N$} & \multicolumn{4}{|c|}{ Hew } & \multicolumn{4}{|c|}{ Minen } \\
\hline & $\cos \%$ & BE.t" & Cort: & SET & Cing. & SEF & Cing. & $S E . P$ & Cñ. & BEth & cont & FEF \\
\hline Labour bove uperens: & D034t+ & ant & $0037+4$ & bont & $0001 \%+4$ & D.SOS & Dongth & $00 m 5$ & $0.042^{t+h}$ & $0 M$ & 0utg-n & A.OAs \\
\hline Gender & 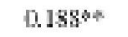 & Met & {$\left[1.47^{k}\right.$} & 00170 & & & & & & & & \\
\hline Edwation & 00280 & aods & $0045^{\text {tan }}$ & 0014 & $0057 t \rightarrow$ & a.d. & Dossth & 0015 & 0.013 & 0022 & 0015:- & 4.021 \\
\hline Oecupational prestige & $-0012^{4+2}$ & s.004 & $-10013^{\text {ph⿱一𫝀口 }}$ & oont & $-002 L+\phi$ & a.105 & $-0002+4$ & 0,05 & -0.003 & 0 ons & Con4 & a.cons \\
\hline No of marriges: & D2y+o & $\operatorname{sig} 7$ & $1213+4$ & ookit & $0354+4$ & $1.1 \% 2$ & $037+4$ & DIKS & 1.058 & onds & 01103 & a.:L4 \\
\hline Nb- of childran & Dosso & ang & Dor7th & 0027 & -0043 & a.ms & Dons & 0030 & O.153oth & 0044 & 0.152 & $\mathrm{acc} 2$ \\
\hline comer proriy & $-0.155^{\text {mot }}$ & mol & $-0275^{*+4}$ & 0075 & $-10373^{4+1}$ & 0.102 & $-0240+$ & 0.099 & 0.114 & 0.135 & -0.199 & 1.129 \\
\hline Me intrsorg'l mows & & & $-12372+4$ & ouls & & & $-0214+4$ & 0021 & & & $-0285 \times$ & 1.:532 \\
\hline Interept & $1.980 \%$ & 0.223 & 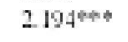 & 0214 & 2458 해 & 0.297 & 2645 为 & 0285 & $1.364^{040}$ & 0304 & $1813=0$ & 4.299 \\
\hline $\mathbf{N}$ & 180 & & 180 & & 95 & & 967 & & 923 & & 923 & \\
\hline F & $19.33^{54}$ & & 40950 the & & 15 sibret & & $2812 \%+4$ & & $11.17^{4}=4$ & & 2]. $\mathrm{B} \mathrm{g}^{\mathrm{a}}=4$ & \\
\hline Adj. Rsquated & 007 & & 0.15 & & Dog & & 1.17 & & d.65 & & 0.14 & \\
\hline thg. in adj. R.squned & & & $00 \mathrm{~s}$ & & & & Dos & & & & ons & \\
\hline
\end{tabular}

Notrs

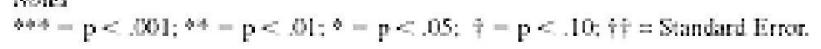

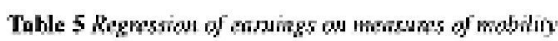

\begin{tabular}{|c|c|c|c|c|c|c|}
\hline \multirow[b]{2}{*}{ Prothor } & \multicolumn{2}{|r|}{ All } & \multicolumn{2}{|r|}{ Men } & \multicolumn{2}{|c|}{ "Homen } \\
\hline & Cong & $X E+$ & Cost' & SE.t & $\cos \bar{c}$ & S.EPt \\
\hline $\begin{array}{l}\text { Labour foros } \\
\text { sxpotiente: }\end{array}$ & $41+.8$ & $140^{6+4}$ & 3565 & $87.0^{64}$ & 4258 & $94.6+6$ \\
\hline Gisnder & -14845.6 & $1212200 x$ & & & & \\
\hline Extuation & 2673.2 & 215.5064 & 3075.3 & $325.1 \% 64$ & 24,76 & $3\rfloor 1.4+* 4$ \\
\hline Decipinanal prstige & 403.5 & teght & 575.3 & $85.8^{4+4}$ & 4247 & $74.4+4$ \\
\hline Na of marriss & 21154 & $10030^{\circ}$ & -1204 & 15,74 & 3548 & $10756^{2 x}$ \\
\hline Mo of children & $-35,5.1$ & 441.4 & $13,32.4$ & $6,402^{\circ}$ & -18153 & $621.4 *+$ \\
\hline Cameer pronigy & 10051.6 & $13501^{8+4}$ & 101764 & $1713.2^{44}$ & 92126 & $1895,4^{2+4}$ \\
\hline $\begin{array}{l}\text { Mo of inta-grg'l } \\
\text { mposs }\end{array}$ & $277+.6$ & $2 n-1 \sin$ & 1731 & $3124^{\text {then }}$ & 4667 & 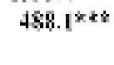 \\
\hline $\begin{array}{l}\text { Mo of inie[-arg'] } \\
\text { mows }\end{array}$ & -1305.0 & $311.90 \%$ & -201.8 & $5007^{404}$ & $-301 \geq 1$ & $488.2 \%+4$ \\
\hline Inlercept & 16967.6 & $3527-4^{004}$ & 195152 & $5163.7^{604}$ & $-10 \% 25$ & 4972.5 \\
\hline $\mathrm{N}$ & \multicolumn{2}{|l|}{188} & \multicolumn{2}{|l|}{9,6} & \multicolumn{2}{|l|}{913} \\
\hline F & \multicolumn{2}{|l|}{$142.42+4$} & \multicolumn{2}{|c|}{$43.4^{506}$} & \multicolumn{2}{|l|}{$57320=$} \\
\hline Adj. $B-s_{1} \mid I_{1}=d$ & \multicolumn{2}{|l|}{0.41} & \multicolumn{2}{|l|}{020} & \multicolumn{2}{|l|}{033} \\
\hline
\end{tabular}

Narts

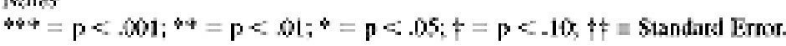

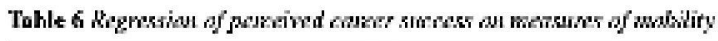

\begin{tabular}{|c|c|c|c|c|c|c|}
\hline \multirow[b]{2}{*}{ Prodichor } & \multicolumn{2}{|c|}{ Ail } & \multicolumn{2}{|c|}{$\mathrm{Mm}$} & \multicolumn{2}{|c|}{ Wwew } \\
\hline & Couf & S.E.FT & Couf. & S.E.t & Cos: & SE.t \\
\hline Famings. & and & DSMAt+4 & c.m & acmith & $\sin$ & acomt \\
\hline $\begin{array}{l}\text { Labour thos } \\
\text { experience }\end{array}$ & 0.00 & $0.957^{4}$ & 605 & 00멓 & 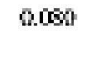 & $\cos$ \\
\hline Gender & 3.54 & $0.710^{++4}$ & & & & \\
\hline Eduratico & -0.110 & 0.129 & - .176 & 0.174 & 602 & a. 104 \\
\hline $\begin{array}{l}\text { Oecupalimal } \\
\text { prestige }\end{array}$ & 0.041 & 0.132 & -0.00 & 0045 & a. $10 \%$ & $0047^{\circ}$ \\
\hline No of marriags & 0.147 & 0.573 & 0. 147 & $0 \pi 9$ & 6. 199 & 0345 \\
\hline No of children & 0.710 & 0.270 & 0.01 & 065 & a.ta & 0.405 \\
\hline Coner pinrily & 0.723 & 0.705 & $0.0 \%$ & 0 6.8 & 1.705 & $|.17|$ \\
\hline Negilive affoct & -6.812 & 0.silgont & -7.603 & $0843^{\circ}$ & $-5.71 \mathrm{~B}$ & 0.9l2hen \\
\hline $\begin{array}{l}\text { No. of inlta -agg'l } \\
\text { moxis }\end{array}$ & -0.496 & $0.168^{+*}$ & 0.477 & 머s & -6.591 & $0.312+$ \\
\hline $\begin{array}{l}\text { No be inlefang'] } \\
\text { mones }\end{array}$ & 0.005 & 0.209 & -0.299 & 0292 & 6372 & 0.302 \\
\hline Inlereapt & 84.122 & $2.440^{++*}$ & $\$ .457$ & $125 \beta^{*+h}$ & $81.5 \%$ & $3.177^{6+t}$ \\
\hline$N$ & 150 & & 955 & & 97 & \\
\hline E & $13.34^{406}$ & & $12.8 s^{+0 *}$ & & $6.9 s^{400}$ & \\
\hline Adj. R-squind & $a n$ & & c.11 & & $\operatorname{ars}$ & \\
\hline
\end{tabular}

Nises

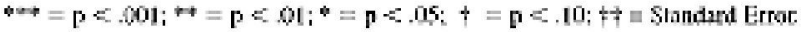


wider gap between aspirations and achievements, thus negatively affecting people's self-evaluations of their success. However, increased inter-organizational mobility has no significant effects on perceived success. The coefficient for this variable is negative for men, and positive for women, which is aligned with hypothesis 12 , but neither coefficient is significant, so overall, we find little support for our last hypothesis.

\section{Discussion}

Given the documented changes unfolding in the economies of many countries, as well as in individual work values, organizational career management practices and women's involvement with the labour force, it is likely that boundaryless career patterns - those characterized by greater inter-organizational mobility - will become increasingly common in the years to come. The boundaryless career concept has received a considerable amount of theoretical attention, but very little empirical testing. The current study, one of the first to make an attempt at operationalizing boundaryless career patterns, compared intra- and inter-organizational mobility among a sample of primarily managerial and professional employees in dual-earner couples in the United States. The goal of the research reported in this article was to reveal what factors contribute to boundaryless and traditional forms of mobility and how these mobility patterns affect objective and subjective career success.

Our results suggest that intra- and inter-organizational mobility are both influenced by gender and family characteristics. Men are more likely to experience job shifts within an employer, while women are more likely to move across employers. Marital instability, number of children and career priority within a couple affect rates of intra- and interorganizational mobility, but the pattern of effects differs by gender. Men's intraorganizational mobility is positively influenced by number of children and career priority, and unaffected by marital instability. By contrast, women's intra-organizational mobility is positively related to number of marriages, negatively related to number of children and unaffected by career priority. With respect to rates of inter-organizational mobility, boundaryless career patterns in men are positively influenced by number of marriages, negatively predicted by career priority and unaffected by number of children. For women, on the other hand, inter-organizational mobility is positively predicted by number of children, but uninfluenced by number of marriages and career priority.

We found that the effects of these mobility patterns on success are equivocal: interorganizational mobility has differing effects on objective and subjective success. Moving between organizations tends to depress earnings, but does not have an effect on how successful people feel in their careers. Job changes within an organization increase earnings, but have a negative effect on perceived success. These relationships hold for both men and women. However, our findings suggest that women pay a price for following a traditional career pattern, while men pay a price for following a boundaryless career pattern. It appears that, to a certain extent, women must choose between their career and their family relationships, and that women's success at work may be 'paid for' with success at home. The women who obtain the greatest objective career success in terms of mobility within a single employer and high earnings are most frequently those who have previously been divorced and who are childless or have fewer children. The picture is not entirely bleak, however, because women with more children actually have higher levels of perceived success in work life, perhaps because their boundaryless career patterns have allowed them to integrate their family demands successfully with their careers. For men, by contrast, the traditional successful career pattern appears to be supported by the traditional family pattern. The men who change jobs with the same employer most frequently and earn the most are also those with the most children. The men who have the most job changes from one employer to another are also those who have been married more times. From a traditional career viewpoint, it seems that women can marry either their career or their family, while men can have a career and a family, but are disadvantaged if they depart from the traditional career pattern. 
Using 1977 data, Bielby and Bielby (1992) found that men's careers were typically given priority over their wives'. More than twenty years later, our data indicate that men's careers are still more frequently given priority, even within dual-career couples. This helps men's objective career success, but probably contributes to women's lower earnings. Furthermore, our findings reflect the enduring nature of traditional gender roles, which assign men primary responsibility for being the earner in the family and women responsibility for child care. Thus we caution that if boundaryless career and traditional career patterns split on gender lines, with men continuing to pursue traditional careers while women pursue boundaryless careers, the boundaryless career could continue to reinforce gender inequities in earnings rather than advancing the cause of women's career success, as has been suggested by boundaryless career advocates (Fondas, 1996).

One important caveat to this study is that it relies on data on dual-earner families from a single country, the United States. Differing labour market policies among countries, as well as family and welfare policies, may have an impact on both rates of intraorganizational and inter-organizational mobility and on the role of family factors in determining career patterns for men and women. Comparative international research on this problem is sorely needed. Studies examining macro-level labour policies, gender-related cultural norms, variations in organizational practices and individually held work values are all needed to illuminate factors that shape career patterns.

This study offers a number of implications for future research. Our results demonstrate that gender and family characteristics exert strong influence over career patterns and subsequent success. Future studies of career paths and career success should control for these variables at the very least, and our findings suggest that a focus on the role of gender and family in shaping careers is likely to be fruitful. While this study provides an initial look at differences between intra- and inter-organizational mobility, future work should take a more fine-grained approach to studying movement within and between employers and measure not only type of job shift, but also whether job shifts were voluntary or involuntary, whether they represented a promotion, lateral transfer or demotion, and what the reason was behind each job shift. Research that relies on comparative national samples provides sophisticated measurement of career patterns and models the effects of gender and family on careers is likely to advance our understanding of contemporary careers throughout a range of national contexts.

\section{Acknowledgements}

The research reported here was supported by the Alfred P. Sloan Foundation (grant numbers 96-6-9 and 99-6-3, Phyllis Moen, Principal Investigator). The authors thank Phyllis Moen and Kathleen Christensen for their ongoing support, and Michael Arthur, Françoise Dany, Mary Mallon, two anonymous reviewers and the staff and fellows of the Cornell Employment and Family Careers Institute: A Sloan Center for the Study of Working Families for helpful comments on earlier drafts of this paper.

\section{References}

Arnold, J. (1997) Managing Careers into the 21st Century. London: Paul Chapman.

Arthur, M.B. and Rousseau, D.M. (eds) (1996) The Boundaryless Career: A New Employment Principle for a New Organizational Era. New York: Oxford University Press.

Arthur, M.B., Hall, D.T. and Lawrence, B.S. (eds) (1989) Handbook of Career Theory. Cambridge: Cambridge 
University Press.

Arthur, M.B., Inkson, K. and Pringle, J.K. (1999) The New Careers: Individual Action and Economic Change. London: Sage.

Bailyn, L. (1989) 'Understanding Individual Experience at Work: Comments on the Theory and Practice of Careers'. In Arthur, M.B., Hall, D.T. and Lawrence, B.S. (eds) Handbook of Career Theory. Cambridge: Cambridge University Press.

Baker, T. and Aldrich, H.E. (1996) 'Prometheus Stretches: Building Identity and Cumulative Knowledge in Multiemployer Careers'. In Arthur, M.B. and Rousseau, D.M. (eds) The Boundaryless Career: A New Employment Principle for a New Organizational Era. New York: Oxford University Press.

Barnett, W.P. and Miner, A.S. (1992) 'Standing on the Shoulders of Others: Career Interdependence in Job Mobility', Administrative Science Quarterly, 37: 262-81.

Bielby, W.T. and Bielby, D.D. (1992) 'I Will Follow Him: Family Ties, Gender-Role Beliefs, and Reluctance to Relocate for a Better Job', American Journal of Sociology, 97: 1241-67.

Blair-Loy, M. (1999) 'Career Patterns of Executive Women in Finance: An Optimal Matching Analysis', American Journal of Sociology, 104: 1346-97.

Blau, F.D., Ferber, M.A. and Winkler, A.E. (2002) The Economics of Women, Men and Work, $4^{\text {th }}$ edn. Upper Saddle River, NJ: Prentice Hall.

Boudreau, J.W., Boswell, W.R. and Judge, T.A. (2001) 'Effects of Personality on Executive Career Success in the U.S. and Europe', Journal of Vocational Behavior, 58: 53-81.

Brett, J.M. and Stroh, L.K. (1997) 'Jumping Ship: Who Benefits from an External Labor Market Career Strategy?', Journal of Applied Psychology, 82: 331-41.

Brett, J.M. and Yogev, S. (1988) 'Restructuring Work for Family: How Dual-Earner Couples with Children Manage', Journal of Social Behavior and Personality, 3: 159-74.

Cadin, L., Bailly-Bender, A.F. and de Saint-Giniez, V. (2000) 'Exploring Boundaryless Careers in the French Context'. In Peiperl, M., Arthur, M., Goffee, R. and Morris, T. (eds) Career Frontiers: New Conceptions of Working Lives. Oxford: Oxford University Press.

Cappelli, P. (ed.) (1999) The New Deal at Work: Managing the Market-Driven Workforce. Boston, MA: Harvard 


\section{Business School Press.}

Cohen, L.E., Broschak, J.P. and Haveman, H.A. (1998) 'And Then There Were More? The Effect of Organizational Sex Composition on the Hiring and Promotion of Managers', American Sociological Review, 63: 711-27.

Cox, T.H. and Harquail, C.V. (1991) 'Career Paths and Career Success in the Early Career Stages of Male and Female MBAs', Journal of Vocational Behavior, 39: 54-75.

DiPrete, T.A. and Soule, W.T. (1986) 'The Organization of Career Lines: Equal Employment Opportunity and Status Advancement in a Federal Bureaucracy', American Sociological Review, 51: 295-309.

Dreher, G.F. and Cox, T.H., Jr (2000) 'Labor Market Mobility and Cash Compensation: The Moderating Effects of Race and Gender', Academy of Management Journal, 43: 890-900.

Ellig, J. and Thatchenkery, T.J. (1996) 'Subjectivism, Discovery, and Boundaryless Careers: An Austrian Perspective'. In Arthur, M.B. and Rousseau, D.M. (eds) The Boundaryless Career: A New Employment Principle for a New Organizational Era. New York: Oxford University Press.

Evans, P. and Bartolomé, F. (1980) Must Success Cost So Much? New York: Basic Books.

Felmlee, D.H. (1982) 'Women's Job Mobility Processes within and between Employers', American Sociological Review, 47: 142-51.

Fondas, N. (1996) 'Feminization at Work: Career Implications'. In Arthur, M.B. and Rousseau, D.M. (eds) The Boundaryless Career: A New Employment Principle for a New Organizational Era. New York: Oxford University Press.

Gallos, J.V. (1989) 'Exploring Women's Development: Implications for Career Theory, Practice, and Research'. In Arthur, M.B., Hall, D.T. and Lawrence, B.S. (eds) Handbook of Career Theory. Cambridge: Cambridge University Press.

Gattiker, U.E. and Larwood, L. (1988) 'Predictors for Managers' Career Mobility, Success, and Satisfaction', Human Relations, 41: 569-91.

Greenhaus, J.H., Parasuraman, S. and Wormley, W.M. (1990) 'Effects of Race on Organizational Experiences, Job Performance Evaluations, and Career Outcomes', Academy of Management Journal, 33: 64-86.

Gunz, H., Evans, M. and Jalland, M. (2000) 'Career Boundaries in a “Boundaryless” World'. In Peiperl, M., Arthur, M., Goffee, R. and Morris, T. (eds) Career Frontiers: New Conceptions of Working Lives. Oxford: Oxford 
University Press.

Hall, D.T. (1976) Careers in Organizations. Santa Monica, CA: Goodyear.

Han, S.-K. and Moen, P. (1998) 'Interlocking Careers: Pathways through Work and Family for Men and Women', IRRA 50th Annual Conference Proceedings. Madison, WI: Industrial Relations Research Association.

Han, S.-K. and Moen, P. (1999) 'Work and Family over Time: A Life Course Approach', Annals of the American Academy of Political and Social Science, 562(March): 98-110.

Heckscher, C.C. (1995) White-Collar Blues: Management Loyalties in an Age of Corporate Restructuring. New York: Basic Books.

Hill, M.S. (1979) 'The Wage Effects of Marital Status and Children', Journal of Human Resources, 14: 579-93. Hirsch, P.M. and Shanley, M. (1996) 'The Rhetoric of Boundaryless - or, How the Newly Empowered Managerial Class Bought into Its Own Marginalization'. In Arthur, M.B. and Rousseau, D.M. (eds) The Boundaryless Career: A New Employment Principle for a New Organizational Era. New York: Oxford University Press. Hochschild, A.R. (1989) The Second Shift: Working Parents and the Revolution at Home. New York: Viking. Hurley, A.E. and Sonnenfeld, J.A. (1998) 'The Effect of Organizational Experience on Managerial Career Attainment in an Internal Labor Market', Journal of Vocational Behavior, 52: 172-90.

Ibarra, H. (1992) 'Homophily and Differential Returns: Sex Differences in Network Structure and Access in an Advertising Firm', Administrative Science Quarterly, 37: 422-47.

Ibarra, H. (1993) 'Personal Networks of Women and Minorities in Management: A Conceptual Framework', Academy of Management Review, 18: 56-87.

Judge, T.A., Cable, D.M., Boudreau, J.W. and Bretz, R.D. (1995) 'An Empirical Investigation of the Predictors of Executive Career Success', Personnel Psychology, 48: 485-519.

Karambayya, R. and Reilly, A.H. (1992) 'Dual Earner Couples: Attitudes and Actions in Restructuring Work for Family', Journal of Organizational Behavior, 13: 585-601.

Kirchmeyer, C. (1998) 'Determinants of Managerial Career Success: Evidence and Explanation of Male/Female Differences', Journal of Management, 24: 673-92.

Korenman, S. and Neumark, D. (1991) 'Does Marriage Really Make Men More Productive?', Journal of Human Resources, 26: 282-307. 
Korenman, S. and Neumark, D. (1992) 'Marriage, Motherhood, and Wages', Journal of Human Resources, 27: 23355.

Korman, A.K., Witting-Berman, U. and Lang, D. (1981) 'Career Success and Personal Failure: Alienation in Professionals and Managers', Academy of Management Journal, 24: 342-60.

Lyness, K.S. and Thompson, D.E. (2000) 'Climbing the Corporate Ladder: Do Female and Male Executives Follow the Same Route?', Journal of Applied Psychology, 85: 86-101.

Marcotte, D.E. (1998) 'The Wage Premium for Job Seniority during the 1980s and Early 1990s', Industrial Relations, 37: 419-39.

Mincer, J. (1978) 'Family Migration Decisions', Journal of Political Economy, 86: 749-73.

Mirvis, P.H. and Hall, D.T. (1996) 'Psychological Success and the Boundaryless Career'. In Arthur, M.B. and Rousseau, D.M. (eds) The Boundaryless Career: A New Employment Principle for a New Organizational Era. New York: Oxford University Press.

Moen, P. (2001) The Career Quandary, Reports on America Vol. 2, No. 1. Washington, DC: Population Reference Bureau.

Moen, P. (ed.) (2003) It's About Time: Couples and Careers. Ithaca, NY: Cornell University Press.

Mroczek, D. and Kolarz, C. (1998) 'The Effects of Age on Positive and Negative Affect: A Developmental Perspective on Happiness'. Journal of Personality and Social Psychology, 75: 1333-49.

Nakao, K. and Treas, J. (1990) Computing 1989 Occupational Prestige Scores, GSS Methodological Report No. 70. Chicago, IL: National Opinion Research Center.

Nardone, T., Veum, J. and Yates, J. (1997) 'Measuring Job Security', Monthly Labor Review, 120: 26-33.

Osterman, P. (1996) Broken Ladders: Managerial Careers in the New Economy. New York: Oxford University Press.

Parasuraman, S., Purohit, Y.S. and Godshalk, V.M. (1996) 'Work and Family Variables, Entrepreneurial Career Success and Psychological Well-Being', Journal of Vocational Behavior, 48: 275-300.

Peiperl, M.A. and Van Der Sluis, E.C.L. (1999) The Experience of Boundarylessness: Job Change, Extrinsic and Intrinsic Career Success among Early-Career MBAs, Working Paper No. 9-02. London: Centre for Organisational Research, London Business School.

Peiperl, M., Arthur, M., Goffee, R. and Morris, T. (eds) (2000) Career Frontiers: New Conceptions of Working Lives. 
Oxford: Oxford University Press.

Pfeffer, J. and Baron, J.N. (1988) 'Taking the Workers Back Out: Recent Trends in the Structuring of Employment'. In Staw, B.M. and Cummings, L.L. (eds) Research in Organizational Behavior, Vol. 10. Greenwich, CT: JAI Press.

Pfeffer, J. and Ross, J. (1982) 'The Effects of Marriage and a Working Wife on Occupational and Wage Attainment', Administrative Science Quarterly, 27: 66-80.

Pixley, J.E. (2000) Career Hierarchy in Dual-Earner Couples: Implications for Occupational Attainment, Working Paper No. 00-14. Ithaca, NY: Bronfenbrenner Life Course Center.

Pleck, J.H. (1985) Working Wives, Working Husbands. Beverly Hills, CA: Sage.

Rosenbaum, J.E. (1979) 'Tournament Mobility: Career Patterns in a Corporation', Administrative Science Quarterly, 24: $220-41$.

Rosenbaum, J.E. (1984) Career Mobility in a Corporate Hierarchy. Orlando, FL: Academic Press.

Rosenfeld, R.A. (1992) 'Job Mobility and Career Processes', Annual Review of Sociology, 18: 39-61.

Scandura, T.A. (1992) 'Mentorship and Career Mobility: An Empirical Investigation', Journal of Organizational Behavior, 13: 169-74.

Schneer, J.A. and Reitman, F. (1990) 'Effects of Employment Gaps on the Careers of M.B.A.'s: More Damaging for Men than for Women?', Academy of Management Journal, 33: 391-406.

Schneer, J.A. and Reitman, F. (1995) 'The Impact of Gender as Managerial Careers Unfold', Journal of Vocational Behavior, 47: 290-315.

Schneer, J.A. and Reitman, F. (1997) 'The Interrupted Managerial Career Path: A Longitudinal Study of MBAs', Journal of Vocational Behavior, 51: 411-34.

Sekaran, U. and Hall, D.T. (1989) 'Asynchronism in Dual-Career and Family Linkages'. In Arthur, M.B., Hall, D.T. and Lawrence, B.S. (eds) Handbook of Career Theory. Cambridge: Cambridge University Press.

Sonnenfeld, J.A. and Peiperl, M.A. (1988) 'Staffing Policy as a Strategic Response: A Typology of Career Systems', Academy of Management Review, 13: 588-600.

Spilerman, S. (1977) 'Careers, Labor Market Structure, and Socioeconomic Achievement', American Journal of Sociology, 83: 551-93. 
Stewman, S. and Konda, S.L. (1983) 'Careers and Organizational Labor Markets: Demographic Models of

Organizational Behavior', American Journal of Sociology, 88: 637-85.

Stier, H., Lewin-Epstein, N. and Braun, M. (2001) 'Welfare Regimes, Family-Supportive Policies, and Women's Employment Along the Life-Course', American Journal of Sociology, 106: 1731-60.

Stroh, L.K., Brett, J.M. and Reilly, A.H. (1992) 'All the Right Stuff: A Comparison of Female and Male Managers' Career Progression', Journal of Applied Psychology, 77: 251-60.

Stroh, L.K., Brett, J.M. and Reilly, A.H. (1996) 'Family Structure, Glass Ceiling, and Traditional Explanations for the Differential Rate of Turnover of Female and Male Managers', Journal of Vocational Behavior, 49: 99-118.

Tharenou, P., Latimer, S. and Conroy, D. (1994) 'How Do You Make It to the Top? An Examination of Influences on Women's and Men's Managerial Advancement', Academy of Management Journal, 37: 899-931.

Tichenor, V.J. (1999) 'Status and Income as Gendered Resources: The Case of Marital Power', Journal of Marriage and the Family, 61: 638-50.

Tolbert, P.S. (1996) 'Occupations, Organizations, and Boundaryless Careers'. In Arthur, M.B. and Rousseau, D.M. (eds) The Boundaryless Career: A New Employment Principle for a New Organizational Era. New York: Oxford University Press.

Tsui, A.S., Pearce, J.L., Porter, L.W. and Tripoli, A.M. (1997) 'Alternative Approaches to the Employee-Organization Relationship: Does Investment in Employees Pay Off?', Academy of Management Journal, 40: $1089-121$.

Turban, D.B. and Dougherty, T.W. (1994) 'Role of Protégé Personality in Receipt of Mentoring and Career Success', Academy of Management Journal, 37: 688-702.

Wayne, S.J., Liden, R.C., Kraimer, M.L. and Graf, I.K. (1999) 'The Role of Human Capital, Motivation and Supervisor Sponsorship in Predicting Career Success', Journal of Organizational Behavior, 20: 577-95.

Wilensky, H.L. (1961) 'Orderly Careers and Social Participation: The Impact of Work History on Social Integration in the Middle Mass', American Sociological Review, 26: 521-39.

Zaun, T. and Landers, P. (2001) 'Job Cutbacks Take a Heavy Toll on Japan: A Spate of Layoffs Weakens Economy and Tradition of Lifetime Employment', Wall Street Journal, 3 August: Section A5. 